\title{
Note
}

\section{Effects of Temperature and Illumination on the Growth of Blue-green Alga Microcystis viridis}

\author{
Norio Ohkubo, Osami Yagi and Mitsumasa Okada
}

\begin{abstract}
A field study was carried out from summer to fall in 1988 to clarify the change in the dominant species of Microcystis in Lake Kasumigaura. Microcystis aeruginosa $\mathrm{f}$. aeruginosa and $M$. aeruginosa f. flos-aquae were dominant in the summer, and $M$. viridis became dominant in the fall. A high correlation was found between the standing crop of $M$. aeruginos $a$ and the water temperature, but the standing crop of $M$. viridis and $\dot{M}$. wesenbergii showed no correlation with the water temperature.

Effects of temperature and illumination on the specific growth rates $(\mu)$ and the algal yield of $M$. viridis $\mathrm{N}-1$ and $M$. viridis NIES 102 were studied with a batch culture. Maximum specific growth rates $\left(\mu_{\max }\right)$ of $M$. viridis $\mathrm{N}-1$ and $M$. viridis NIES 102 were observed at 25 and $30^{\circ} \mathrm{C}$, respectively. $M$. viridis could grow at lower temperature than the other species of Microcystis. M. viridis N-1 could not grow under continuous illumination of 2,000 $\mathrm{k}$ but did so under periodic illumination. The specific growth rate of $M$. viridis was lower than for other Microcystis species.

These results suggested that $M$. viridis was more difficult to dominate than other Microcystis in summer.
\end{abstract}

Key words: blue-green alga, Microcystis, specific growth rate, water bloom

\section{Introduction}

Many workers have studied the ecological and physiological characteristics of Microcystis both in the field and in the laboratory. Some environmental factors, such as high water temperatures above $20^{\circ} \mathrm{C}$, the formation of thermocline, the high $\mathrm{pH}$ value from 9 to 11 in the water surface layer, and the high irradiance were important for water bloom formation of Microcystis (Окino, 1973).

Physiological studies on Microcystis developed by the use of the pure culture (Gerloff et al., 1950). McLachlan and Gorham (1962) reported that the $\mathrm{pH}$ from 6.5 to 10 and nitrogen sources such as nitrate, ammonium and urea were important for the growth of $M$. aeruginosa. We have studied the growth charac- teristics of two species of Microcystis ( $M$. aeruginosa $\mathrm{K}-3 \mathrm{~A}$ and $M$. flos-aquae $\mathrm{K}-5$ strains) isolated from Lake Kasumigaura and reported the following results (YAGI et al., 1984). The maximum specific growth rate $\left(\mu_{\max }\right)$ of these Microcystis strains was observed at $35^{\circ} \mathrm{C}$, and the nitrogen and phosphorus concentration for the $\mu_{\max }$ of these strains were 1.0 and $0.05 \mathrm{mg}$. $1^{-1}$, respectively. Moreover, one of the heterotrophic bacteria, Moraxella nonliquefaciens, increased the specific growth rate and the maximum growth yield of $M$. aeruginosa $\mathrm{K}-3 \mathrm{~A}$ (Kumagai et al., 1986). Amemiya et al. (1990) investigated the factors affecting the dominance of Microcystis species in Lake Suwa. They reported that $M$. aeruginosa became dominant at a relatively high nitrogen concentration and both $M$. aeruginosa and $M$. wesenbergii 
could grow better than $M$. viridis at a higher light intensity.

In recent years, Kusumi et al. (1987) reported that $M$. viridis produced a toxic substance which was a pentapeptide. It is very important to control the growth of $M$. viridis. However, only a few researchers have studied its growth characteristics. The present study was conducted to clarify the factors influencing the growth of $M$. viridis. We studied the change in the dominant species of Microcystis from summer to fall in Lake Kasumigaura, and the temperature and illumination effects on the growth of $M$. viridis in the laboratory.

\section{Materials and methods}

\section{2-1. Determination of algal standing crop}

Algal cell numbers were counted with a photomicroscope. The algal flocks were compressed previously to count the cell numbers. The classification of the four species of $\mathrm{Mi}$ crocystis was based on the system as reported by KомÂré (1958). Water samples were collected from the yacht harbor in Lake Kasumigaura using a $100 \mathrm{~cm}$ water column sampler. The water temperature was measured by thermometer.

\section{2-2. Test algae}

$M$. viridis $\mathrm{N}-1$ and $M$. viridis NIES 102 were used in this experiment. A single cell of $M$. viridis $\mathrm{N}-1$ was isolated from an algal flock sample in Lake Kasumigaura utilizing the capillary-pipette method in 1986. An axenic strain of $M$. viridis NIES 102 was provided from the culture collection of The National Institute for Environmental Studies. M. viridis $\mathrm{N}-1$ has the characteristic of colony forming, but $M$. viridis NIES 102 loses that characteristic.

\section{2-3. Medium}

Table 1 shows the composition of $\mathrm{M}-11$ medium which is a modified Gorham medium (Hughes et al., 1958). To avoid the formation of precipitation, the solutions of $\mathrm{K}_{2} \mathrm{HPO}_{4}$ and ferric citrate were autoclaved separately at $121^{\circ}$ $\mathrm{C}$ for $15 \mathrm{~min}$. These solutions were added axenically before using the M-11 medium.

\section{2-4. Cultivation}

Test algae were cultured in $100 \mathrm{ml}$ of $\mathrm{M}-11$
Table 1. Composition of M-11 medium.

\begin{tabular}{lr}
$\mathrm{NaNO}_{3}$ & $100 \mathrm{mg}$ \\
$\mathrm{K}_{2} \mathrm{HPO}_{4}$ & $10 \mathrm{mg}$ \\
$\mathrm{MgSO}_{4} \cdot 7 \mathrm{H}_{2} \mathrm{O}$ & $75 \mathrm{mg}$ \\
$\mathrm{CaCl}_{2} \cdot 2 \mathrm{H}_{2} \mathrm{O}$ & $40 \mathrm{mg}$ \\
$\mathrm{Na}_{2} \mathrm{CO}_{3}$ & $20 \mathrm{mg}$ \\
$\mathrm{Fe}-\mathrm{citrate}$ & $6 \mathrm{mg}$ \\
$\mathrm{Na}_{2}$ EDTA $\cdot 2 \mathrm{H}_{2} \mathrm{O}$ & $1 \mathrm{mg}$ \\
Deionized Water & 11 \\
$\mathrm{pH}$ & 8.0 \\
\hline
\end{tabular}

medium in a $200 \mathrm{ml}$ Erlenmeyer flask under illumination provided by a fluorescent lamp. The illumination cycle consisted of alternating $12 \mathrm{hr}$ periods of illumination and darkness at $25^{\circ}$ C. One milliliter of $100 \mathrm{mg} \cdot \mathrm{I}^{-1}$ of pre-cultured algae was inoculated in $100 \mathrm{ml}$ of M-11 medium and cultured under the same conditions as the pre-culture.

\section{2-5. Measurement of cell growth and spe- cific growth rate}

The biomass was estimated from algal cell numbers and cell volume using a coulter counter (Coulter Counter Electronics Inc., Model ZM-II). The algal cell numbers and cell volume were converted to algal dry weight $\left(\mathrm{mg} \cdot \mathrm{1}^{-1}\right)$ by a calibration curve. The specific growth rate, $\mu\left(\mathrm{d}^{-1}\right)$ was calculated in the logarithmic phase using the following equation (1).

$$
\mu=\frac{1}{t-t_{0}} \cdot \ln \frac{N}{N_{0}}
$$

$N$ : Algal concentration at $t$ time $\left(\mathrm{mg} \cdot \mathrm{l}^{-1}\right)$

$N_{0}$ : Algal concentration at $t_{0}$ time $\left(\mathrm{mg} \cdot \mathrm{l}^{-1}\right)$

$t$ : Cultivation time (day)

$t_{0}$ : Starting time of logarithmic phase (day)

\section{Results and discussion}

\section{3-1. Changes in components of Microcys- tis species in Lake Kasumigaura}

Figure 1 shows the seasonal changes in abundance of four species of Microcystis in Lake Kasumigaura in 1988. The abundance of cell numbers of $M$. aeruginosa $\mathrm{f}$. aeruginosa and $M$. aeruginosa f. flos-aquae were $c a .6 \times 10^{2}$ and $1 \times$ $10^{3}$ cells $\cdot \mathrm{ml}^{-1}$ on $12 \mathrm{July}$, and increased to the maximum amounts of $c a .1 \times 10^{5}$ and $7 \times 10^{4}$ 




Fig. 1. Seasonal changes in cell numbers of four species of Microcystis in Lake Kasumigaura.

cells $\cdot \mathrm{ml}^{-1}$ on 24 August. The abundance of cell numbers of $M$. aeruginosa $\mathrm{f}$. aeruginosa and M. aenuginosa f. flos-aquae reduced to $c a .4 \times 10^{3}$ and $2 \times 10^{3}$ cells $\cdot \mathrm{ml}^{-1}$ on 8 September, respectively, and decreased to less than $10^{2}$ cells $\cdot \mathrm{ml}^{-1}$ on 4 October. $M$. viridis maximized $c a .1 \times 10^{4}$ cells $\cdot \mathrm{ml}^{-1}$ on 24 August and did not decrease from September to October. The maximum cell number of $M$. wesenbergii was $c a .4 \times 10^{2}$ cells $\cdot \mathrm{ml}^{-1}$ on 8 September. $M$. aeruginosa tended to be dominant in summer, while $M$. viridis did so in fall.

Takamura and Watanabe (1987) also reported that $M$. aeruginosa f. aeruginosa and $M$. aeruginosa f. flos-aquae tended to predominate in the early stage of the bloom or sometimes throughout the bloom, while $M$. viridis tended to predominate in the middle and late stage of the bloom from 1982 to 1985 .

Table 2 shows the correlation coefficients between water temperature and the cell number of each species from June to November. There are high correlations between the water temperature and the cell number of $M$. aeruginosa or total cell number of four Microcystis. But no correlation was observed between water temperature and the cell number of $M$. viridis or $M$. wesenbergii. Takahashl et al. (1981) also reported a positive correlation between total cell number of Microcystis and water temperature by the method of multi-regression analysis. These results suggested that the effect of water temperature on the standing crop of Microcystis was different for each species. 
Table 2. Correlation coefficients between cell numbers of Microcystis and water temperature in Lake Kasumigaura.

\begin{tabular}{lccc}
\multicolumn{1}{c}{ Species } & $\begin{array}{c}\text { Regression } \\
\text { equation }\end{array}$ & $\begin{array}{c}\text { Correlation } \\
\text { coefficient }\end{array}$ & $\begin{array}{c}\text { Sample } \\
\text { number }\end{array}$ \\
\hline M. aenuginosa f. aenuginosa & $\log Y=0.27 x-3.09$ & 0.867 & 22 \\
M. aenuginosa f. flos-aquae & $\log Y=0.27 x-4.11$ & 0.716 & 15 \\
M. viridis & $\log Y=0.23 x-4.06$ & 0.393 & 19 \\
M. wesenbergii & $\log Y=0.11 x-2.30$ & 0.314 & 22 \\
Total of four Microcystis & $\log Y=0.25 x-3.14$ & 0.838 & 22 \\
\hline
\end{tabular}

\section{3-2. Effect of temperature on the algal growth}

Effects of temperature on $\mu$ values of the $\mathrm{N}$ 1 and NIES 102 strains under the periodic or continuous illumination of $2,000 \mathrm{~lx}$ are shown in Figure 2. Since the $\mathrm{N}-1$ strain did not grow under the continuous illumination of $2,000 \mathrm{~lx}$, it was cultivated only under the periodic illumination, when $\mu$ values of the N-1 and NIES 102

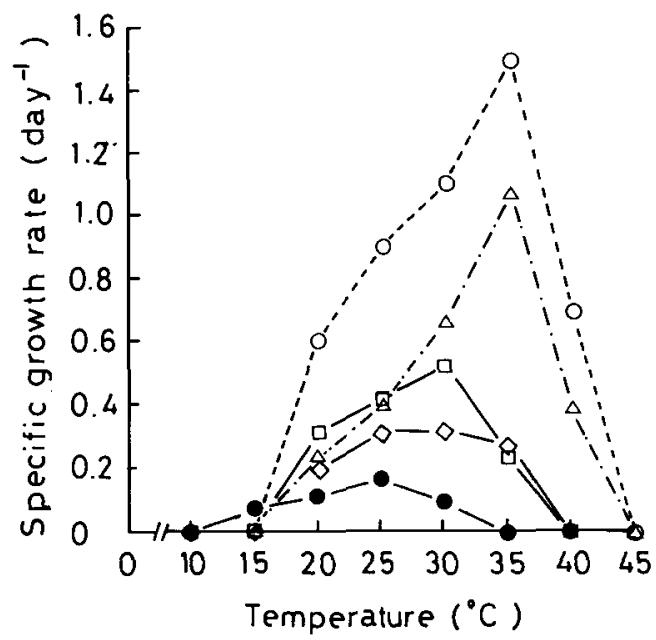

Fig. 2. Effect of temperature on the specific growth rate of Microcystis at 2,000 lx.

- $M$. viridis $\mathrm{N}-1$, periodic illumination* $\diamond: M$. viridis NIES 102 , periodic illumination*

$\square$ : M. viridis NIES 102, continuous illumination*

$\mathrm{O}:$ M. aeruginosa $\mathrm{K}-5$, continuous illumina. tion**

$\triangle: M$. wesenbergii $\mathrm{K}-3 \mathrm{~A}$, continuous illumination**

*Present experiment ${ }^{* *}$ YAGI (1984) strains were 0.11 and $0.2 \cdot \mathrm{d}^{-1}$ at $20^{\circ} \mathrm{C}, 0.17$ and 0 . $32 \cdot \mathrm{d}^{-1}$ at $25^{\circ} \mathrm{C}$, and 0.09 and $0.32 \cdot \mathrm{d}^{-1}$ at $30^{\circ} \mathrm{C}$, respectively. The $\mu_{\max }$ values of the $\mathrm{N}-1$ and NIES 102 strains were observed at $25^{\circ} \mathrm{C}$ and $25^{-}$ $30^{\circ} \mathrm{C}$, respectively. The $\mu$ value of the $\mathrm{N}-1$ strain was lower than that of the NIES 102 strain above $20^{\circ} \mathrm{C}$. The $\mathrm{N}-1$ strain could not grow at $35^{\circ} \mathrm{C}$, but could do so at $15^{\circ} \mathrm{C}$. This result indicates that the $\mathrm{N}-1$ strain can grow at lower temperature than the NIES 102 strain. The $\mu$ value of the NIES 102 strain under continuous illumination was 1.6 -fold of that under periodic illumination at $30^{\circ} \mathrm{C}$. We earlier observed $\mu_{\max }$ values of $M$. aeruginosa $\mathrm{K}-5$ and $M$. wesenbergii $\mathrm{K}-3 \mathrm{~A}$ at $35^{\circ} \mathrm{C}$ ( $\mathrm{YAGI}$ et al., 1984). These facts show that the $\mathrm{N}-1$ and NIES 102 strains grow more slowly above $30^{\circ} \mathrm{C}$ than the $\mathrm{K}-5$ and $\mathrm{K}-3 \mathrm{~A}$ strains.

Figure 3 shows the effect of temperature on the algal yields of the N-1 and NIES 102 strains under continuous or periodic illumination at 2 , $000 \mathrm{~lx}$. The algal yield indicated normal growth for long periods. Maximum algal yields of the $\mathrm{N}-1$ and NIES 102 strains were 580 $\mathrm{mg} \cdot \mathrm{l}^{-1}$ at $25^{\circ} \mathrm{C}$, and $c a .400 \mathrm{mg} \cdot \mathrm{l}^{-1}$ between 20 and $30^{\circ} \mathrm{C}$, respectively, under periodic illumination. The algal yield of the $\mathrm{N}-1$ strain was 180 $\mathrm{mg} \cdot 1^{-1}$ at $15^{\circ} \mathrm{C}$, whereas that of NIES 102 strain was not detected at $15^{\circ} \mathrm{C}$. Therefore, the $\mathrm{N}-1$ strain can grow at a lower temperature than the NIES 102 strain.

\section{3-3. Effect of light intensity on algal growth}

Figure 4 shows the effect of light intensity on the $\mu$ values of four strains of Microcystis. The $\mu$ values of the $\mathrm{N}-1$ strain ranged from 0.09 to $0.18 \cdot \mathrm{d}^{-1}$ between 500 and $10,000 \mathrm{~lx}$, while those 




Fig. 3. Effect of temperature on the algal yield of $M$. viridis $\mathrm{N}-1$ and $M$. viridis NIES 102 at $2,000 \mathrm{~lx}$.

: $M$. viridis $\mathrm{N}-1$, periodic illumination

А : $M$. viridis NIES 102 , periodic illumination

$\triangle: M$. viridis NIES 102, continuous illumination

of the NIES 102 strain ranged from 0.10 to 0.34 • $\mathrm{d}^{-1}$ between 500 and $5,000 \mathrm{~lx}$ under periodic illumination. The $\mu$ value of the $\mathrm{N}-1$ strain was lower than that of the NIES 102 strain. The $\mu_{\max }$ value of the $\mathrm{N}-1$ strain was $0.18 \cdot \mathrm{d}^{-1}$ between 2,000 and $3,000 \mathrm{~lx}$, and that of NIES 102 strain was $0.34 \cdot \mathrm{d}^{-1}$ at $4,000 \mathrm{~lx}$ under periodic illumination.

The effect of periodic or continuous illumination on the $\mu$ value of the NIES 102 strain is also shown in Figure 4. The continuous illumination increased the $\mu$ value of the NIES 102 strain at the range of 1.3-to 2.0-fold compared to the periodic illumination at $25^{\circ} \mathrm{C}$ through all light intensity. However, the continuous illumination reduced the $\mu$ value of the NIES 102 strain above $4,000 \mathrm{~lx}$ at $30^{\circ} \mathrm{C}$. The $\mu_{\max }$ value of $M$. aeruginosa $\mathrm{K}-5$ was $c a .1 .4 \cdot \mathrm{d}^{-1}$ at $5,0001 \mathrm{x}$ under continuous illumination, and the $\mu_{\max }$ value of $M$. wesenbergii $\mathrm{K}-3 \mathrm{~A}$ was $c a \cdot 0.8 \cdot \mathrm{d}^{-1}$ between 3,000 and 4,000 $\mathrm{lx}$ under continuous illumination at $30^{\circ} \mathrm{C}$. On the other hand, the $\mu_{\max }$ value of $M$. viridis NIES 102 was $c a .0 .5$. $\mathrm{d}^{-1}$ between 2,000 and 3,000 $\mathrm{lx}$.

Figure 5 shows the effect of light intensity on the algal yields of $M$. viridis N-1 and NIES 102

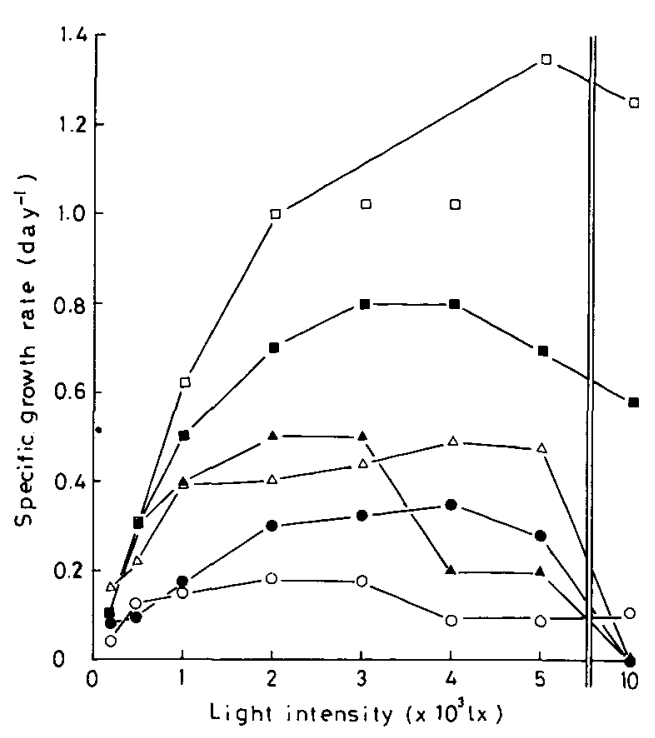

Fig. 4. Effect of light intensity on the specific growth rate of $M$. viridis $\mathrm{N}-1$ and $M$. viridis NIES 102 at 25 and $30^{\circ} \mathrm{C}$.

$\mathrm{O}$ : M. viridis $\mathrm{N}-1$, at $25^{\circ} \mathrm{C}$, periodic illumination*

- $M$. viridis NIES 102 , at $25^{\circ} \mathrm{C}$, periodic illumination*

$\triangle:$ M. viridis NIES 102 , at $25^{\circ} \mathrm{C}$, continuous illumination*

A: $M$. viridis NIES 102 , at $30^{\circ} \mathrm{C}$, continuous illumination*

$\square$ : $M$. aeruginos $\mathrm{K}-5$, at $30^{\circ} \mathrm{C}$, continuous illumination**

a: $M$. wesenbergii $\mathrm{K}-3 \mathrm{~A}$, at $30^{\circ} \mathrm{C}$, continuous illumination**

*Present experiment ${ }^{* *} \mathrm{Y}_{\text {AGI }}(1984)$

strains under continuous or periodic illumination. The $\mathrm{N}-1$ strain showed a high maximum algal yield of $570 \mathrm{mg} \cdot \mathrm{l}^{-1}$ at $2,000 \mathrm{~lx}$ under periodic illumination. The maximum algal yield of the NIES 102 strain at $25^{\circ} \mathrm{C}$ was $c a .400$ $\mathrm{mg} \cdot \mathrm{l}^{-1}$ between 2,000 and 4,000 $\mathrm{lx}$ under periodic illumination, and $300 \mathrm{mg} \cdot \mathrm{1}^{-1}$ under continuous illumination. The maximum algal yield of the NIES 102 strain at $30^{\circ} \mathrm{C}$ was $480 \mathrm{mg} \cdot \mathrm{l}^{-1}$ at $1,000 \mathrm{~lx}$ under continuous illumination.

The $\mu$ value and the algal yield are very important factors in algal bloom formation. The $\mu$ values of $M$. viridis $\mathrm{N}-1$ and NIES 102 were lower than those of $M$. aeruginosa $\mathrm{K}-5$ and 


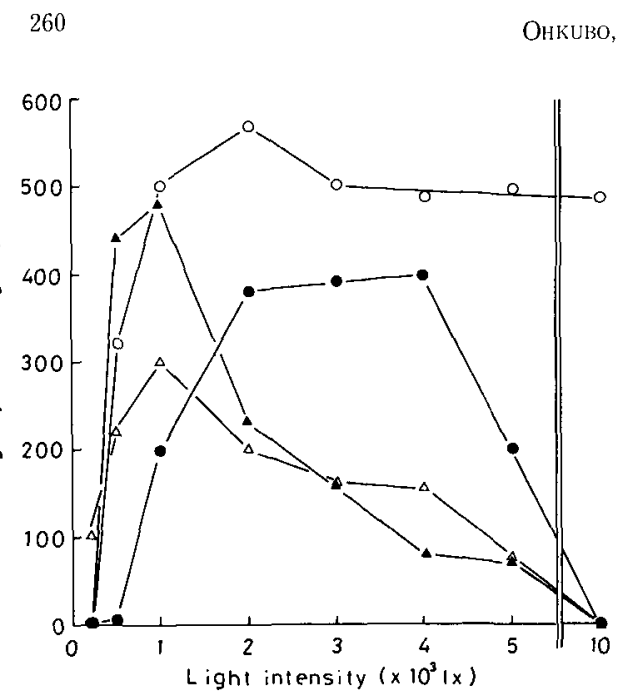

Fig. 5. Effect of light intensity on the algal yields of $M$. viridis $\mathrm{N}-1$ and $M$. viridis NIES 102 at 25 and $30^{\circ} \mathrm{C}$.

$\mathrm{O}: M$. viridis $\mathrm{N}-1$, at $25^{\circ} \mathrm{C}$, periodic illumination

- $M$. viridis NIES 102 , at $25^{\circ} \mathrm{C}$, periodic illumination

$\triangle: M$. viridis NIES 102 , at $25^{\circ} \mathrm{C}$, continuous illumination

$\Delta$ : $M$. viridis NIES 102 , at $30^{\circ} \mathrm{C}$, continuous illumination

M. wesenbergii $\mathrm{K}-3 \mathrm{~A}$. A low $\mu$ is disadvantageous for the water bloom formation of $M$. viridis. It is not certain why the $\mu$ value of $M$. viridis is low. Since the N-I strain could not grow under continuous illumination, we investigated the effects of continuous or periodic illumination on the specific growth rate and the algal yield. The $\mu$ values under continuous illumination were generally higher than with periodic illumination. However, continuous illumination inhibits algal growth under specific conditions.

BRAND and GuillaRd (1981) reported that many phytoplankton species cultured under the continuous illumination showed higher cell multiplication than under periodic illumination. However, a few species of phytoplankton had a high sensitivity to continuous illumination, and could not grow even if light intensity was very low. Loogman et al. (1980) investigated the effect of the length of light period on the growth of Oscillatoria agardhii under saturated light irradiance and reported that the efficiency of light-energy incorporation decreased as the length of the light period increased. There are two possible explanations for this phenomenon: (1) The faster growing cells under the longer photoperiod may have a higher respiratory rate, and (2) there may be a time-dependent inhibition of photosynthesis which progressively increases during the light period. In the present study, $M$. viridis ( $\mathrm{N}-1$ strain) exhibited no tolerance to continuous illumination above $25^{\circ} \mathrm{C}$. The effects of continuous and periodic illumination on the growth of $M$. viridis are clarified.

\section{Conclusion}

From the above observations and experiments, we concluded as follows.

1) $M$. aenuginosa $\mathrm{f}$. aeruginosa and $M$. aeruginosa f. flos-aquae were dominant in summer, but $M$. viridis became dominant in the fall of 1988 in Lake Kasumigaura. 2) M. viridis could grow at lower temperature than other Microcystis species. 3) The specific growth rate of $M$. viridis was lower than for other species of Microcystis. 4) In summer, M. aeruginosa was dominant but $M$. viridis was not.

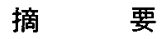

藍藻類 Microcystis viridis の增殖に及ぼす 温度と照度の影響

霞ヶ浦に出現した Microcystis 属 4 種の現存量の 変化ならびに，霞ヶ浦の水の華より単藻化した $M$. viridis $\mathrm{N}-1$ 株抢よび国立環境研究所保存菌株であ る $M$. viridis NIES 102 株を用いて増殖に及ぼす 温度と照度の影響を調べ，霞ヶ浦における $M$. vir idis の発生要因について検討を加えた。

1988 年の霞ヶ浦土浦港では, M. aeruginosa $\mathrm{f}$. aeruginosa と $M$. aeruginosa f. flos-aquae が夏に 優占種となり，M. viridis は秋に優占種となる傾向 が認められた。 $M$. aeruginosa f. aeruginosa およ び M. aeruginosa f. flos-aquae の現存量は水温と 高い相関を示したが，M. viridis 扔よびM. wesen-

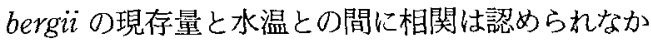
った。

$M$. viridis $\mathrm{N}-1$ は $25^{\circ} \mathrm{C}$ で最大の比増殖速度 （ $\mu$ ）を示し， $15^{\circ} \mathrm{C}$ でも増殖が可能であった。また 
M. viridis NIES 102 は $25 \sim 30^{\circ} \mathrm{C}$ で最大の $\mu$ を示 した。M. viridis $\mathrm{N}-1$ 株は他の Microcystis 属より も低温で增殖が可能な株と考えられ，夏期には優 占種になりにくいものと考えられた。

\section{References}

AmemiYa, Y., T. Okino and O. Nakayama (1990): Factors possibly affecting dominance of $\mathrm{Mi}$ crocystis species. Jpn. J. Limnol., 51: 9-13.

Brand, L. E. and R. R. L. Guillard (1981): The effects of continuous light and light intensity on the reproduction rates of twenty-two species of marine phytoplankton. F. exp. mar. Biol. Ecol., 50: 119-132.

Gerloff, G. C., G. P. Fitzgerald and F. Skoog (1950): The isolation, purification and culture of blue-green algae. Am. J. Bot., 37: 216-218.

Hughes, E. O., P. R. Gorham and A. Zehnder (1958): Toxicity of a unialgal culture of $\mathrm{Mi}$ crocystis aemuginosa. Can. J. Microbiol., 4: 225236.

KOMÁREK, J. (1958): Die taxonomische Revision der planktischen Blaualgen der Tschechoslowakei, p. 10-206. In J. KOMÁREK and H. ETTL (eds.), Algologische Studien. Tschechoslowakischen Akademie der Wissenshaften.

Kumagai, M., Y. Takamura, O. Yagi and R. Sudo (1986): Interactions between Microcystis aeruginosa and Moraxella nonliquefaciens. Jpn. J. Limnol., 47: 219-228 (in Japanese).

Kusumi, T., T. Ool, M. M. Watanabe, H. TAKAHASH and H. KaKISAWA (1987): Cyanoviridin $\mathrm{RR}$, a toxin from the cyanobacterium (blue-green alga) Microcystis viridis. Tetrahedron Letters, 28: 4695-4698.

Loogman, J. G., A. F. Post and L. R. Mur (1980): The influence of periodicity in light conditions as determined by the trophic state of the water, on the growth of the green alga Scenedesmus protuberans and the cyanobacterium Oscillatoria agardhii, p. 79-82. In J. BARICA and L. R. MUR (eds.), Hypertrophic Ecosystem, Junk, Den Haag.

MCLachlan, J. and P. R. Gorham (1962): Effect of $\mathrm{pH}$ and nitrogen sources on growth of Microcystis aeruginosa Kütz. Can. J. Microbiol., 8: 1-11.

Okıno, T. (1973): Studies on the blooming of Microcystis aenuginosa. Jpn. J. Bot., 20:381-402.

Takahashi, M., I. Nomura, M. Komatsu and S. ICHIMURA (1981): Multi-regression analysis of Microcystis bloom with various environmental parameters in eutrophic Lake Kasumigaura, Japan. Verh. Internat. Verein. Limnol., 21: 659 $-663$.

Takamura, N. and M. M. Watanabe (1987): Sea. sonal changes in the biomass of four species of Microcystis in Lake Kasumigaura. Jpn. J. Limnol., 48: S139-S144.

Yagi, O., T. Hagiwara, Y. TakamuRa and R. Sudo (1984): Growth characteristics of axenic and unialgal Microcystis isolated from Lake Kasumigaura. Jpn. J. Wat. Pollut. Res., 7: 496503 (in Japanese).

(Authors: Norio OнкUво, Moriyama Waterworks, Bureau of Water Supply, Hitachi City, 4-4-1, Moriyama, Hitachi, Ibaraki, 316, Japan; Osami YAGI, The National Institute for Environmental Studies, 16-2, Onogawa, Tsukuba, Ibaraki 305, Japan; Mitsumasa OKADA, Faculty of Science, Toho University, 2-2-1, Miyama, Funabashi, Chiba 274; 大久保紀男, 日立市企業局森山浄水場, $\bar{\top} 316$ 茨城 䀠日立市森山町 4-4-1; 矢木修身, 国立環境研究所, 广 305 茨城県つくば市小野川 16-2; 岡田光正, 東邦大

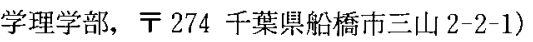

Received: 25 June 1990 Accepted: 25 June 1991 